\title{
The Central Nervous System as a Site of Action for the Coronary Vasoconstrictor Effect of Digoxin
}

\author{
Hasan Garan, Thomas W. Smith, and Wm. John Powell, Jr. \\ From the Cardiac Unit and the Department of Medicine of the Massachusetts \\ General Hospital and the Department of Medicine of Harvard Medical School, \\ Boston, Massachusetts 02114
}

A B S TRACT Digitalis is known to have a vasoconstrictor effect in the coronary circulation. Recent studies have demonstrated that the coronary vasoconstrictor effects of acetylstrophanthidin and digoxin are neurally mediated via alpha adrenergic fibers. In the present study, experiments were done in 20 dogs anesthetized with chloralose and urethane to study the central nervous system as a possible site of action for this vasoconstrictor effect of digoxin. After the intravenous administration of $1.0 \mathrm{mg}$ digoxin, cerebrospinal fluid concentrations of digoxin rose to a peak of $2.3 \pm 0.4$ (SEM) $\mathrm{ng} / \mathrm{ml}$ at $15 \mathrm{~min}$, temporally corresponding to the peak in coronary vascular resistance change of $+20.0 \pm$ $2.5 \%$ of control in the paced canine heart. Submicrogram digoxin injections into the lateral cerebral ventricle produced a significant increase in coronary vascular resistance, the latter injection producing a peak increase in coronary vascular resistance of $12.4 \pm 1.2 \%$ of control. Cross-perfusion experiments, where the isolated head of the operative dog was perfused from a donor dog receiving digoxin, thus keeping digoxin levels in the remainder of the operative dog very low, showed a similar degree of coronary vasoconstriction. Thus, the central nervous system appears to be an important site of action for the early coronary vasoconstrictor effect of digoxin.

\section{INTRODUCTION}

Digitalis has been known to have a constrictor effect in several vascular beds (1-3). Vatner, Higgins, Franklin, and Braunwald extended these observations to the coronary vascular bed and demonstrated a ouabain-induced coronary vasoconstriction in conscious dogs (4). Until

A preliminary report of this work was presented at the 57th Annual Meeting of the Federation of American Societies for Experimental Biology (Fed. Proc. 1973. 32: 718. (Abstr.)

Received for publication 17 October 1973 and in revised form 13 August 1974. recently, it had been thought that a direct action of digitalis on vascular smooth muscle was the major cause of this vasoconstrictor effect $(1,3)$. Nerve recordings, however, have provided evidence that the digitalis glycosides exert significant effects on the afferent and efferent autonomic nervous system (5-7). Recent studies in our laboratory have demonstrated that the greatest portion of digoxin-induced coronary vasoconstriction and of acetylstrophanthidin-induced vasoconstriction in skeletal muscle is neurogenically mediated and occurs through stimulation of alpha adrenergic receptors $(8,9)$. This effect appears to be due to the action of digitalis at or proximal to the sympathetic ganglia.

The present study was undertaken to determine the site of action of the coronary vasoconstrictor effect of digoxin. Specifically, the central nervous system $(\mathrm{CNS})^{1}$ was investigated as a likely locus at which cardiac glycosides act to bring about this vasoconstrictor effect.

\section{METHODS}

20 mongrel dogs weighing between 18 and $22 \mathrm{~kg}$ were anesthetized with intravenous chloralose $(60 \mathrm{mg} / \mathrm{kg})$ and urethane $(600 \mathrm{mg} / \mathrm{kg})$. After the induction of anesthesia, an endotracheal tube was inserted. The animals were ventilated with a Harvard positive pressure respirator (Harvard Apparatus Co., Inc., Millis, Mass.) with $100 \%$ oxygen. Similarly anesthetized donor dogs were exsanguinated from one femoral artery. $50-100 \mathrm{~cm}^{3}$ of sodium bicarbonate (44 $\left.\mathrm{meq} / 50 \mathrm{~cm}^{3}\right)$ and $20 \mathrm{~cm}^{3}$ of heparin $\left(1,000 \mathrm{U} / \mathrm{cm}^{3}\right)$ were added to the collected blood of the donor dog, and this blood was used when necessary in some experiments as described below.

In animals undergoing surgery, a right thoracotomy was performed. Care was taken during the surgical procedure to avoid damage to the neural supply (both sympathetic and vagal) to the heart. Coronary blood flow was measured by cannulating the coronary sinus by the method described by Gregg and Fisher (10). After the thoracotomy, a wide-bore

${ }^{1}$ Abbreviations used in this paper: CNS, central nervous system; CSF, cerebrospinal fluid; LV dp/dt, first derivitive of left ventricular pressure with respect to time. 


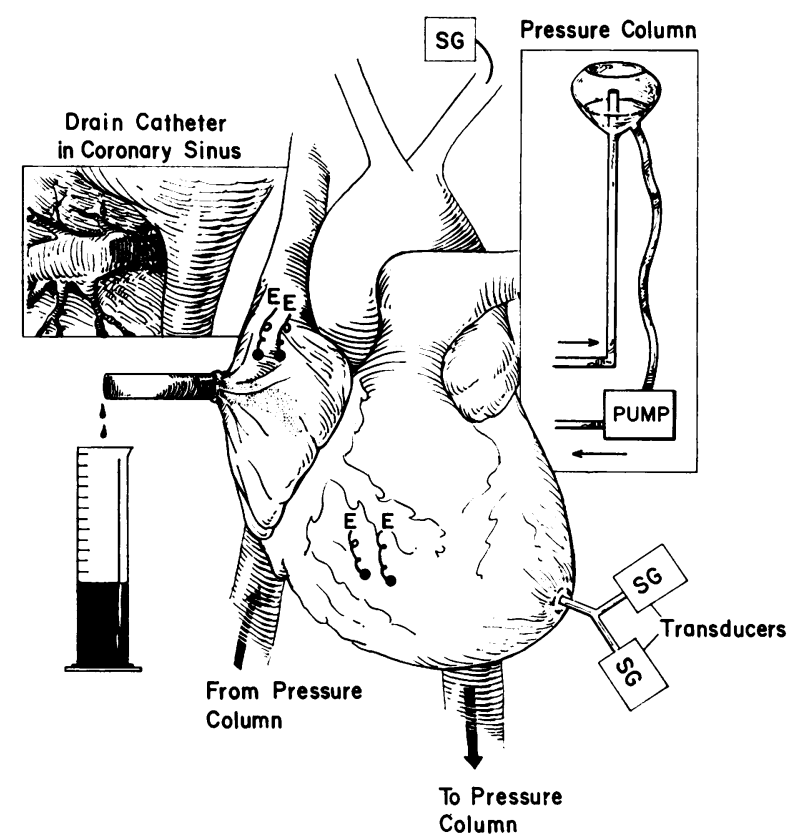

FIGURE 1 Schematic diagram of the canine preparation used for the experiments. A view of the posterior surface of the heart showing the catheter ligated in place near the orifice of the coronary sinus is in the insert on the upper left. The cardiotomy funnel and the pump used to maintain systemic pressure at a near constant level is shown on the upper right. SG, strain gauge; E, pacing electrode. See text for details.

(Bardic \#16, Bard Parker Co., Inc., Div. Becton, Dickinson \& Co., Danbury, Conn.) cannula was inserted through the right atrial appendage and ligated in place in the most distal end of the coronary sinus. Care was taken to assure that there was no occlusion of the small venous tributaries emptying into the coronary sinus near the right atrium (Fig. 1). The cannula was held in a horizonal position by a brace, thus preventing motion that might lead to transient occlusion of these small tributaries. The distal end of this cannula was connected to a short rigid T-tube placed at the level of the right atrium. The lower arm of the T-tube drained freely, and the upper arm remained open to air. Although coronary venous pressure was not measured, in a previous study (9) coronary sinus pressure was monitored and remained constant (within $1 \mathrm{~cm} \mathrm{H}_{2} \mathrm{O}$ of the control value) after the intravenous injection of 1.0 $\mathrm{mg}$ of digoxin. The control values were always between +1 and $-3 \mathrm{~cm} \mathrm{H}_{2} \mathrm{O}$. Coronary sinus outflow, a close approximation of total coronary blood flow, was quantitated by direct 1-min collections of the venous blood in a graduated cylinder. Although a small percentage of coronary blood flow is returned directly to the left ventricle via the Thebesian system, it seems unlikely that the results observed could be due entirely to the redistribution of coronary blood flow to the Thebesian system.

To maintain systemic blood pressure constant, blood from the femoral artery of the dog was allowed to overflow into a cardiotomy funnel as shown in Fig. 1. The volume that overflowed into the funnel was returned to the dog via the femoral vein at a constant rate by the use of a roller pump. The pump was automatically stopped by a photo-

1366 H. Garan, T. W. Smith, and W. J. Powell, Jr. electric cell when the blood in the funnel fell below a certain level. The pump restarted when the volume accumulated above this level. This assured a near constant blood volume in the operative dog despite possible changes in venous capacitance. A tendency toward a slight increase or a slight decrease in the dog's systemic blood pressure resulted in an increase or a decrease in overflow and thus, a near constant systemic blood pressure. In several dogs in which the systemic pressure fell below the level of overflow toward the end of the experiment, blood from a donor dog was added to keep the systemic pressure stable.

The heart of the operative animal was paced with a Medtronic Model 5837 atrioventricular (Medtronic, Inc., Minneapolis, Minn.) to keep the heart rate and atrioventricular interval constant throughout each experiment. The pacing electrodes were sutured onto the epicardial surface of the right atrium and of the right ventricle, and atrioventricular sequential pacing was employed. In each experiment a pacing rate slighty above the intrinsic rate of the dog was chosen to assure consistent atrioventricular capture.

A rigid wide-bore cannula, inserted into the apex and sutured in place, was used to measure left ventricular systolic and end-diastolic pressures. Arterial pressure was measured in the brachial artery and central venous pressure in the superior vena cava. All pressures were recorded with Statham P23Db pressure transducers (Statham Instruments, Inc., Oxnard, Calif.). The electrocardiogram, arterial blood pressure, left ventricular pressure, left ventricular end-diastolic pressure, first derivative of left ventricular pressure with respect to time ( $\mathrm{LV} \mathrm{dp} / \mathrm{dt}$ ), and central venous pressure were recorded on a Sanborn Model 350 oscillograph (Hewlett-Packard Co., Waltham Div., Waltham, Mass.). LV dp/dt was obtained by resistance capacitor electronic differentiation of the full left ventricular pressure. Calibration of the $\mathrm{dp} / \mathrm{dt}$ differentiator was accomplished by supplying a wave form of known slope to the differentiating circuit, which has a time constant of $0.001 \mathrm{~s}$ and a cutoff of $160 \mathrm{cycle} / \mathrm{s}$.

Blood gases, electrolyte concentrations, and hematocrit were determined before, during, and at the end of the experimental runs. The values were $\mathrm{Po}_{2} 204 \pm 25 \mathrm{~mm} \mathrm{Hg}$, $\mathrm{PCO}_{2} 40.3 \pm 1.7 \mathrm{~mm} \mathrm{Hg}, \mathrm{pH} 7.32 \pm 0.02$; sodium $147 \pm 3 \mathrm{meq} /$ liter, potassium $3.4 \pm 0.5 \mathrm{meq} / \mathrm{liter}$, and hematocrit $44.6 \pm$ $2.9 \%$. The response observed in the dogs with slight metabolic acidosis was not in any consistent way different from the response in nonacidotic ones. Positive end expiratory pressure of $3-5 \mathrm{~cm} \mathrm{H}_{2} \mathrm{O}$ was maintained by the respirator, and the arterial $\mathrm{Po}_{2}$ remained above $100 \mathrm{~mm} \mathrm{Hg}$ during the experiments.

Digoxin concentrations in plasma and cerebrospinal fluid (CSF) were measured by radioimmunoassay $(11,12)$. CSF samples were obtained via a 20 -gauge spinal needle inserted into the cisternum magnum posteriorly. The sample size was $0.3-0.5 \mathrm{~cm}^{8}$. To each sample was added $0.5 \mathrm{ml}$ of plasma, and the total volume was brought to $1.0 \mathrm{ml}$, if necessary, by addition of buffered saline ( $150 \mathrm{mM}$ sodium chloride, $10 \mathrm{mM}$ sodium phosphate, $\mathrm{pH}$ 7.4). Total CSF removed from a dog during one experiment did not exceed $4 \mathrm{~cm}^{3}$. CSF remained clear during the first 20-min of every experiment. In three dogs in which CSF became bloody late in the experiment, CSF hematocrits did not exceed $5 \%$.

In each experiment a period of $20 \mathrm{~min}$ of stable coronary flow was observed before administering digoxin. Coronary vascular resistance was calculated as the ratio of mean aortic pressure and coronary sinus blood flow, and ex- 
pressed in units of millimeters of mercury per cubic centimeter per minute. Changes in coronary vascular resistance were expressed as percent changes from control values before the injection of digoxin. Statistical evaluation was by Student's $t$ test (paired) and the results considered significant when the $P$ value was less than 0.05 in doubletailed distribution.

\section{Experimental procedures}

Injection of digoxin into CSF. In nine dogs a hole was drilled on the coronal suture of the skull $1 \mathrm{~cm}$ lateral to the sagittal sinus. The tip of a 20 -gauge spinal needle was advanced into a cerebral ventricle through this hole. Another 20-gauge spinal needle was placed in the cisternum magnum. In seven dogs $0.1 \mu \mathrm{g}(100 \mathrm{ng})$ of digoxin (Lanoxin, Burroughs Wellcome \& Co., Inc., Tuckahoe, N. Y.) in $0.1 \mathrm{ml}$ of modified Krebs-Ringers solution (143 mM sodium, $4.0 \mathrm{mM}$ potassium, $2.5 \mathrm{mM}$ calcium, $1.3 \mathrm{mM}$ magnesium, $1.3 \mathrm{mM}$ phosphate, $126 \mathrm{mM}$ chloride, $25 \mathrm{mM} \mathrm{bi-}$ carbonate. and $5.5 \mathrm{mM}$ glucose), $\mathrm{pH} 7.35$, was injected into the cerebral ventricle via the first needle and flushed with $0.9 \mathrm{ml}$ of the same buffer. The cisternal needle drained freely during the injection. Digoxin determinations could be carried out on CSF samples subsequently obtained via the cisternal needle. By this method the drug was injected in the direction of physiological flow of CSF. Control in- jections into a cerebral ventricle of $1.0 \mathrm{ml}$ of vehicle (propylene glycol $40 \%$, ethanol $10 \%$, and a sufficient quantity of water for injection in $0.1 \mathrm{ml}$ of modified KrebsRinger solution) and flush solution alone preceded the administration of digoxin. Control injections of the vehicle alone resulted in less than a $1-2 \%$ change in coronary vascular resistance and the associated hemodynamics during a 20 -min follow-up period. In each of two additional animals the control solution (vehicle and flush) was injected twice at 20-min intervals and coronary vascular resistance was calculated at 1 and subsequently at 5-min intervals for up to $1 \mathrm{~h}$ after the second injection.

Cross-head perfusion. In seven dogs all structures were sectioned across the neck at the level of $\mathrm{C} 4$ except the vagus nerve and the vertebral column and its contents. In the operative dog both common carotid arteries (just below the carotid sinuses) and both vertebral arteries were cannulated. These received blood from the femoral arteries of a support dog. Venous blood from the superior vena cava of the operative dog was returned to the support dog via the femoral veins of the latter. The subclavian arteries distal to the origin of the vertebral arteries and the azygos vein were tied off in the operative dog. As described above, the femoral arteries of the operative dog were connected to the overflow column, consisting of a cardiotomy funnel and pump. The arterial pressure perfusing the head of the

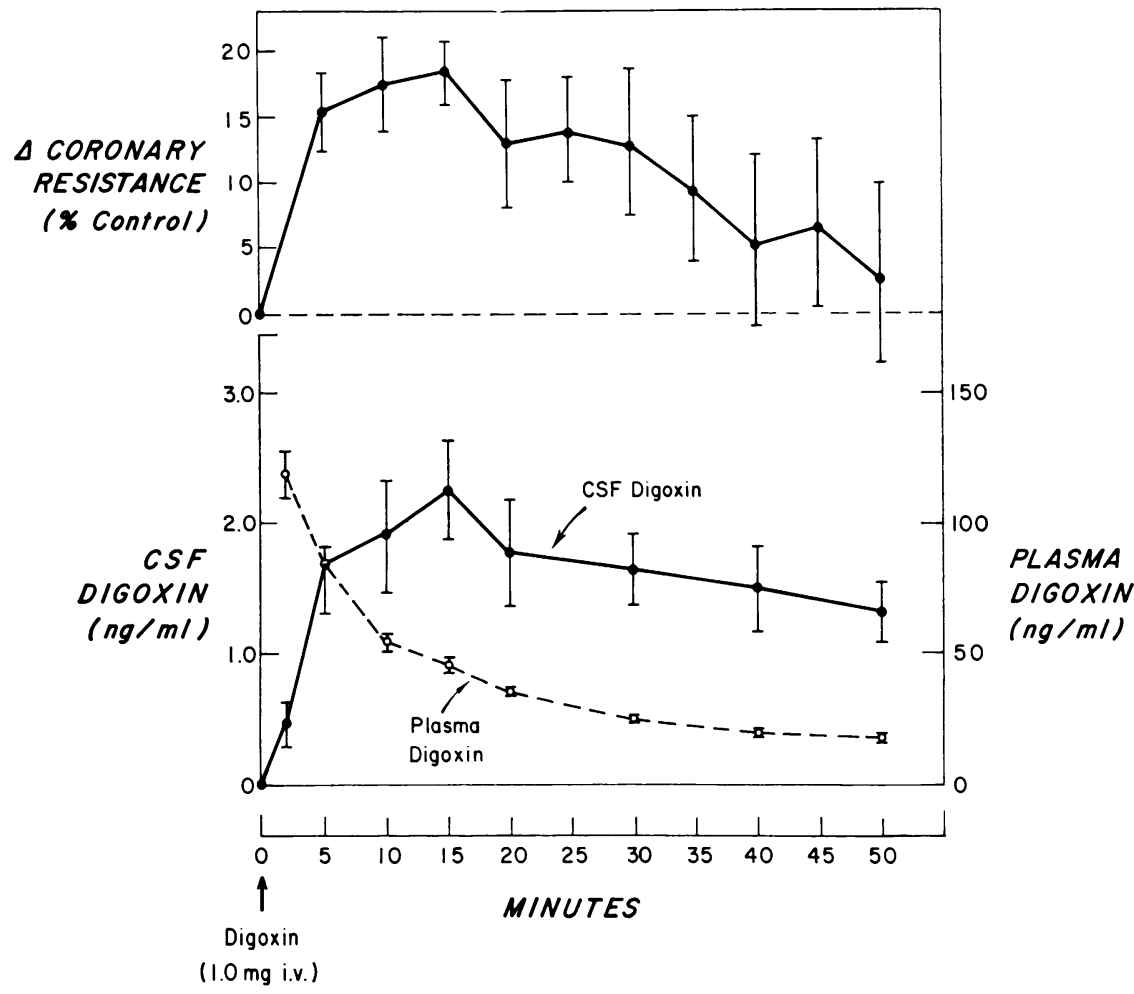

Figure 2 The upper panel shows the effect of intravenous digoxin $(1.0 \mathrm{mg})$ on coronary vascular resistance $(n=9)$. The lower panel demonstrates CSF (solid line) and plasma (dashed line) digoxin concentrations after intravenous digoxin $(1.0 \mathrm{mg})(n=4)$. Note the close temporal correlation between coronary vascular resistance and CSF digoxin levels. In the control period before the administration of i.v. digoxin, five vascular resistance determinations at $1-\mathrm{min}$ intervals were within $1 \frac{1}{2} \%$ of each other $(9)$. The vertical bars represent \pm 1 SEM. 


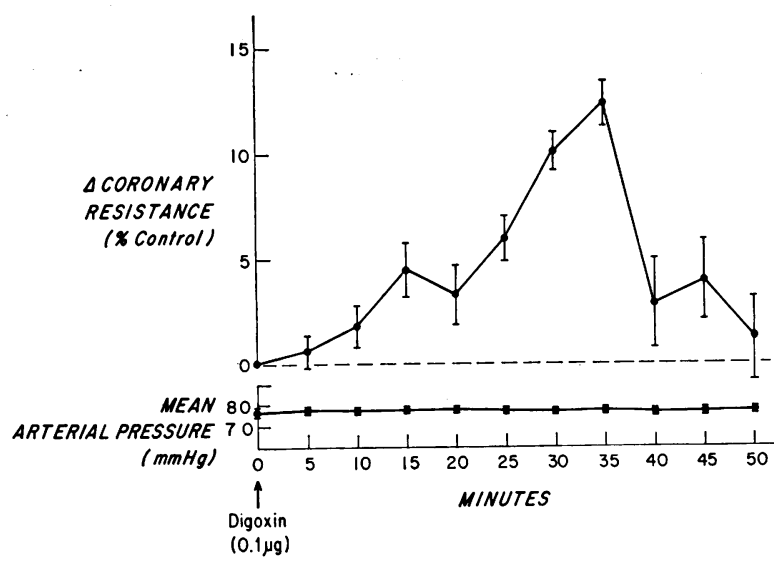

FIGURE 3 Plot of mean coronary vascular resistance in seven dogs after injection of digoxin $(0.10 \mu \mathrm{g})$ into a cerebral ventricle. The coronary vascular resistance is significantly higher than the control value at 25,30 , and $35 \mathrm{~min}$ after the injection, and peaks at $35 \mathrm{~min}$. The lower panel demonstrates the mean arterial pressure. In the control period, before the intraventricular administration of digoxin, five vascular resistance determinations each at 5-min intervals were within $3 \%$ of each other. The vertical bars represent \pm 1 SEM.

operative dog was monitored from the catheter connecting the femoral arteries of the support dog to the carotid arteries immediately adjacent to the head of the operative dog. This remained stable throughout each experiment. After the termination of surgery and at the end of the experiment, intactness of autonomic nervous supply of the heart was tested by the response to carotid artery clamping.

In six dogs digoxin in a dose of $1.0 \mathrm{mg}$ was administered intravenously to the support dog. Coronary blood flow of the operative dog was serially measured as described above.
Simultaneous arterial blood samples were obtained from both dogs at fixed time intervals after the injection to allow determination of plasma digoxin concentrations. In an additional dog a similar protocol was followed but $1.0 \mathrm{mg}$ of digoxin was given intravenously to the operative dog and the coronary blood flow of both the operative dog and the support dog was serially measured.

\section{RESULTS}

Digoxin concentrations in CSF. The lower panel of Fig. 2 demonstrates the CSF concentrations of digoxin after $1.0 \mathrm{mg}$ of intravenous digoxin in four anesthetized dogs. The drug level in the CSF rises to a peak value of $2.3 \pm 0.4$ (SEM) $\mathrm{ng} / \mathrm{ml}$ at $15 \mathrm{~min}$ and gradually declines thereafter, but remains greater than $1.0 \mathrm{ng} / \mathrm{ml}$ at the end of $50 \mathrm{~min}$. The dashed line on the same panel, drawn to a scale of 50 times larger, demonstrates the plasma digoxin concentrations of these dogs. The top panel shows the neurally mediated, sustained rise in coronary vascular resistance after the intravenous administration of $1.0 \mathrm{mg}$ digoxin observed in nine other dogs in experiments done previously in our laboratory (9). These data demonstrate the close correlation between the temporal course of CSF levels of digoxin and changes in coronary vascular resistance. Digoxin reaches maximum concentrations in CSF coincident with peak neurally mediated vasoconstriction. Thus, the time course of the movement of digoxin across the blood-brain barrier is compatible with a CNS site of the vasoconstrictor effect.

Injection of digoxin into cerebral ventricles. In seven dogs anesthetized with chloralose and urethane, injection of $0.1 \mu \mathrm{g}$ of digoxin into a cerebral ventricle produced an increase in coronary vascular resistance,

TABLE I

Mean Hemodynamic Data after $0.1 \mu \mathrm{g}$ of Digoxin into a Cerebral Ventricle*

\begin{tabular}{|c|c|c|c|c|c|c|c|c|c|}
\hline $\begin{array}{l}\text { Time after } \\
\text { injection } \\
\text { of digoxin }\end{array}$ & $\begin{array}{l}\Delta \text { coronary } \\
\text { vascular } \\
\text { resistance }\end{array}$ & $\begin{array}{l}\text { Mean } \\
\text { arterial } \\
\text { pressure }\end{array}$ & $\begin{array}{c}\text { Pulse } \\
\text { pressure }\end{array}$ & $\begin{array}{l}\text { Peak left } \\
\text { ventricular } \\
\text { pressure }\end{array}$ & $\begin{array}{c}\text { Left } \\
\text { ventricular } \\
\mathrm{dp} / \mathrm{dt}\end{array}$ & $\begin{array}{c}\text { Left } \\
\text { ventricular } \\
\text { end-diastolic } \\
\text { pressure }\end{array}$ & $\begin{array}{l}\text { Central } \\
\text { venous } \\
\text { pressure }\end{array}$ & $\begin{array}{l}\text { Heart } \\
\text { rate }\end{array}$ & $\begin{array}{c}\text { Mean CSF } \\
\text { digoxin } \\
\text { concentration }\end{array}$ \\
\hline $\min$ & $\%$ control & $m m \mathrm{Hg}$ & $m m \mathrm{Hg}$ & $m m \mathrm{Hg}$ & $m m B g / s$ & $\mathrm{~cm} \mathrm{H}_{2} \mathrm{O}$ & $\mathrm{cm} \mathrm{H}_{2} \mathrm{O}$ & $\min ^{-1}$ & $\mathrm{ng} / \mathrm{cm}^{\mathrm{s}}$ \\
\hline Control & 0 & $77 \pm 3$ & $55 \pm 10$ & $102 \pm 5$ & $1,900 \pm 280$ & $8.7 \pm 0.8$ & $7.5 \pm 1.0$ & $154 \pm 6$ & 0 \\
\hline 5 & $+0.6 \pm 0.9$ & $77 \pm 3$ & $54 \pm 10$ & $100 \pm 5$ & $1,910 \pm 280$ & $8.1 \pm 0.9$ & $7.6 \pm 1.1$ & $154 \pm 6$ & $4.8 \pm 2.3$ \\
\hline 10 & $+1.8 \pm 1.0$ & $77 \pm 3$ & $55 \pm 10$ & $102 \pm 5$ & $1,950 \pm 280$ & $8.7 \pm 1.0$ & $7.4 \pm 1.0$ & $154 \pm 6$ & $3.2 \pm 1.3$ \\
\hline 15 & $+4.5 \pm 1.3$ & $78 \pm 4$ & $54 \pm 9$ & $103 \pm 5$ & $1,920 \pm 260$ & $8.7 \pm 0.6$ & $7.4 \pm 0.9$ & $154 \pm 6$ & - \\
\hline 20 & $+3.3 \pm 1.5$ & $77 \pm 4$ & $52 \pm 8$ & $101 \pm 4$ & $1,770 \pm 150$ & $8.6 \pm 0.5$ & $7.6 \pm 1.0$ & $154 \pm 6$ & $2.8 \pm 1.2$ \\
\hline 25 & $+6.0 \pm 1.1$ & $77 \pm 3$ & $53 \pm 8$ & $101 \pm 4$ & $1,810 \pm 240$ & $8.6 \pm 0.4$ & $7.5 \pm 1.0$ & $154 \pm 6$ & - \\
\hline 30 & $+10.1 \pm 0.9$ & $78 \pm 4$ & $54 \pm 8$ & $101 \pm 5$ & $1,860 \pm 270$ & $9.5 \pm 0.9$ & $7.5 \pm 1.0$ & $154 \pm 6$ & $1.6 \pm 0.9$ \\
\hline 35 & $+12.4 \pm 1.2$ & $77 \pm 3$ & $54 \pm 9$ & $100 \pm 5$ & $1,910 \pm 270$ & $8.6 \pm 0.6$ & $7.6 \pm 1.0$ & $154 \pm 6$ & - \\
\hline 40 & $+2.9 \pm 2.1$ & $77 \pm 3$ & $54 \pm 8$ & $100 \pm 5$ & $1,840 \pm 220$ & $8.7 \pm 0.7$ & $7.5 \pm 0.9$ & $154 \pm 6$ & - \\
\hline 45 & $+4.0 \pm 1.9$ & $77 \pm 3$ & $53 \pm 8$ & $99 \pm 4$ & $1,740 \pm 200$ & $8.6 \pm 0.6$ & $7.6 \pm 0.9$ & $154 \pm 6$ & - \\
\hline 50 & $+1.2 \pm 2.0$ & $77 \pm 3$ & $52 \pm 8$ & $100 \pm 5$ & $1,760 \pm 220$ & $9.0 \pm 0.8$ & $7.8 \pm 0.9$ & $154 \pm 6$ & $0.8 \pm 0.5$ \\
\hline
\end{tabular}

This table shows the hemodynamic data associated with the coronary vascular resistance changes depicted in Fig. 3 . In the control period before the intraventricular administration of digoxin, five hemodynamic determinations, each at 5-min intervals, were within $3 \%$ of each other. $n=7$. 


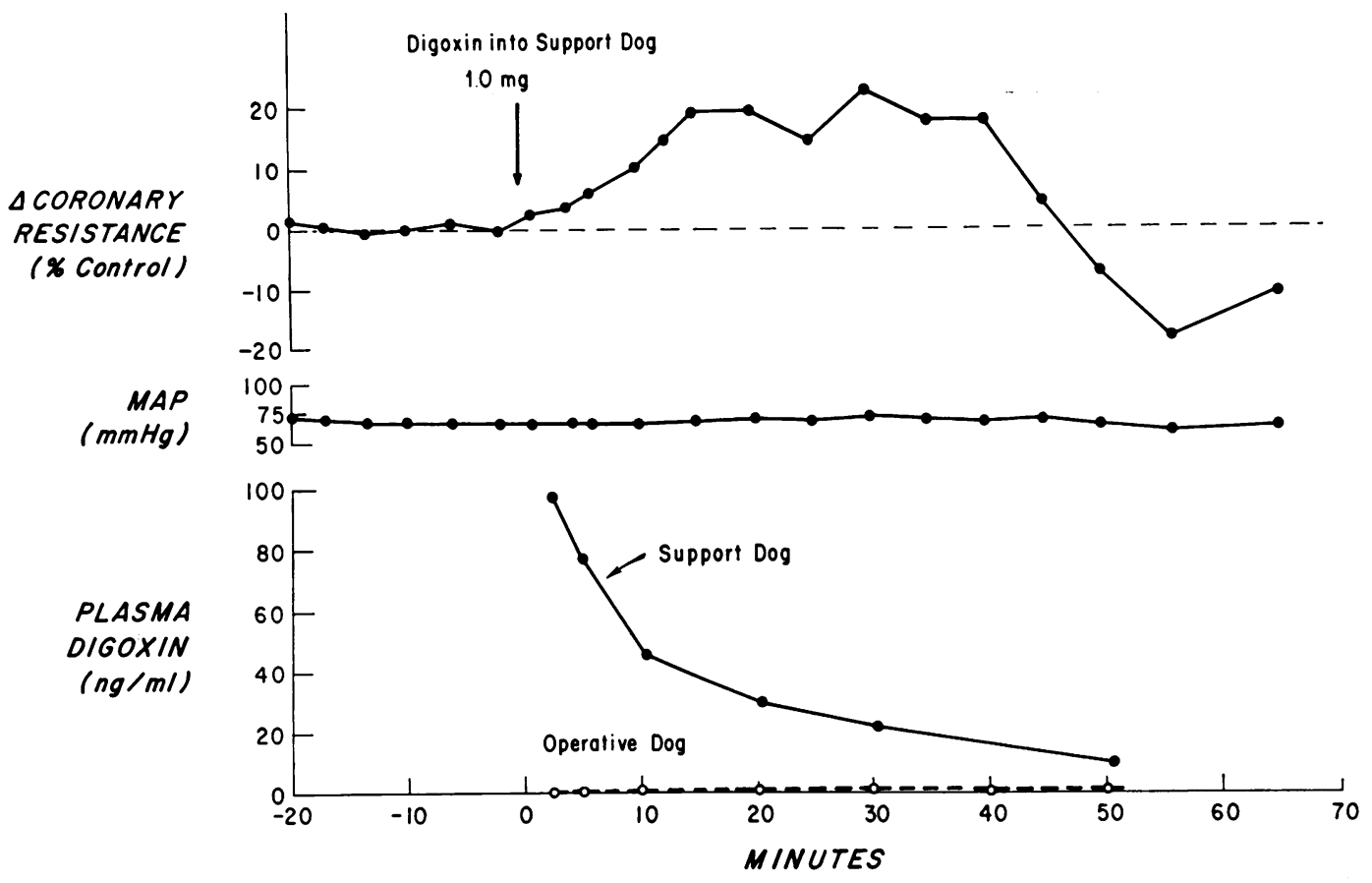

FIGURE 4 Coronary vascular resistance of the operative dog in a cross-perfusion preparation after injection of digoxin (1.0 mg i.v.) into the support dog. The middle panel shows the plasma digoxin levels in the support and operative dogs. Note the sustained increase in coronary vascular resistance in the operative dog despite very low $(<0.50 \mathrm{ng} / \mathrm{ml})$ plasma digoxin levels.

which had a peak value of $+12.4 \pm 1.2 \%$ of control (Fig. 3). The effect was significant $(P<0.04)$ from 25 through $35 \mathrm{~min}$. The mean control resistance was $1.2 \pm 0.1 \mathrm{~mm} \mathrm{Hg} / \mathrm{cm} / \mathrm{min}$.

Table I summarizes the mean hemodynamic data from these seven dogs. Mean aortic pressure, pulse pressure,

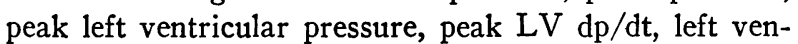
tricular end-diastolic pressure, and central venous pressure remained stable. Heart rate was maintained constant for each experiment. Thus, there was no change in the hemodynamic correlates of myocardial oxygen consumption.

CSF digoxin concentrations were measured in five of the seven dogs. The mean values obtained in cisternal CSF samples after injection into the cerebral ventricles are included in Table I. The peak levels exceeded CSF digoxin concentrations obtained by the injection of 1.0 $\mathrm{mg}$ digoxin i.v., but the decline in these levels was more rapid. This decline presumably reflects the flow of CSF as well as uptake by CNS tissues.

In each of two additional dogs two control injections of the vehicle alone were made into the CSF at 20 -min intervals. A $1 \mathrm{~h}$ followup period after the second injection revealed little change in coronary vascular resistance. In one animal the changes in resistance ranged between -8.5 and $-3.5 \%$ of the control level. In the other animal the changes ranged between -4.4 and $+3.9 \%$ of the control level.

Cross-head perfusion. In five experiments out of six in which the cerebral circulation of the operative dog was supplied by arterial blood from the support dog, coronary vascular resistance increased after $1.0 \mathrm{mg}$ of digoxin injected intravenously into the support dog. Data from a representative experiment are illustrated in Fig. 4. The upper panel shows the increase in coronary vascular resistance, which peaked at a value of $+22 \%$ of control 30 min after intravenous administration of digoxin to the support dog. Control resistance was $0.6 \mathrm{~mm} \mathrm{Hg} / \mathrm{cm}^{3} / \mathrm{min}$. Fig. 4 also shows the mean arterial pressure and the plasma digoxin concentrations in the operative and support dogs. There was very little mixing between the two circulations, as judged by plasma digoxin levels in the operative dog, which remained less than $0.5 \mathrm{ng} / \mathrm{ml}$ throughout the experiment.

The data for coronary vascular resistance, coronary blood flow, and mean arterial pressure from the six experiments are shown in Table II. The heart was paced in each experiment. In the five animals that demonstrated an increase in coronary vascular resistance after administration of intravenous digoxin to the support dog, peak vascular resistance ranged from $+11 \%$ to $+35 \%$ of control values in four animals. In one experiment

Coronary Vasoconstrictor Effect of Digoxin

1369 
TABLE II

Coronary Vascular Resistance, Coronary Flow, Mean Arterial Pressure, and

\begin{tabular}{|c|c|c|c|c|c|c|c|c|c|}
\hline \multirow[b]{2}{*}{$\begin{array}{l}\text { Time after } \\
\text { injection } \\
\text { of digoxin }\end{array}$} & \multicolumn{3}{|c|}{ Dog 1} & \multicolumn{3}{|c|}{ Dog 2} & \multicolumn{3}{|c|}{ Dog 3} \\
\hline & $\begin{array}{l}\Delta \text { coronary } \\
\text { vascular } \\
\text { resistance }\end{array}$ & $\begin{array}{l}\text { Coronary } \\
\text { flow }\end{array}$ & $\begin{array}{c}\text { Mean } \\
\text { arterial } \\
\text { pressure }\end{array}$ & $\begin{array}{l}\Delta \text { coronary } \\
\text { vascular } \\
\text { resistance }\end{array}$ & $\begin{array}{l}\text { Coronary } \\
\text { flow }\end{array}$ & $\begin{array}{c}\text { Mean } \\
\text { arterial } \\
\text { pressure }\end{array}$ & $\begin{array}{l}\Delta \text { coronary } \\
\text { vascular } \\
\text { resistance }\end{array}$ & $\begin{array}{l}\text { Coronary } \\
\text { flow }\end{array}$ & $\begin{array}{c}\text { Mean } \\
\text { arterial } \\
\text { pressure }\end{array}$ \\
\hline $\min$ & $\%$ control & $\mathrm{cm}^{2} / \mathrm{min}$ & $m m \mathrm{Hg}$ & $\%$ control & $\mathrm{cm}^{3} / \min$ & $m m \mathrm{Hg}$ & $\%$ control & $\mathrm{cm}^{2} / \mathrm{min}$ & $m m \mathrm{Hg}$ \\
\hline Control & 0 & 48 & 83 & 0 & 53 & 88 & 0 & 87 & 83 \\
\hline 5 & +1.8 & 46 & 80 & +0.6 & 51 & 85 & +2.1 & 80 & 77 \\
\hline 10 & +7.0 & 42 & 77 & -5.4 & 53 & 83 & +7.4 & 74 & 75 \\
\hline 15 & +11.1 & 38 & 72 & -18.7 & 63 & 85 & +10.6 & 72 & 75 \\
\hline 20 & +7.0 & 40 & 73 & -7.8 & 47 & 72 & +13.8 & 70 & 75 \\
\hline 25 & +2.3 & 40 & 70 & -5.4 & 51 & 80 & +7.4 & 74 & 77 \\
\hline 30 & 0 & 41 & 70 & -9.6 & 48 & 72 & +10.6 & 74 & 77 \\
\hline 35 & o & 42 & 72 & -3.6 & 47 & 75 & +10.6 & 74 & 77 \\
\hline 40 & -10.0 & 41 & 63 & -5.4 & 51 & 80 & +19.2 & 71 & 80 \\
\hline 45 & -28.0 & 61 & 75 & -3.6 & 47 & 75 & +19.2 & 71 & 80 \\
\hline 50 & -24.0 & 58 & 75 & -4.1 & 49 & 78 & +12.8 & 73 & 77 \\
\hline 55 & -19.0 & 64 & 88 & +0.6 & 48 & 80 & +9.5 & 74 & 77 \\
\hline 60 & -19.0 & 64 & 88 & -4.8 & 46 & 73 & +7.4 & 78 & 75 \\
\hline
\end{tabular}

This table summarizes the experimental data from cross-head perfusion experiments in each of six dogs. In the control period before the administration of digoxin, five vascular resistance determinations, each at 5-min intervals, were within $3 \%$ of each other.

there was no increase in coronary vascular resistance, but coronary flow decreased by a small amount. In four of the five animals observed for more than $40 \mathrm{~min}$, coronary resistance fell below the control level, thus raising the possibility of a second site of action of digoxin in the head and neck with opposing effects and a different time course of action.

Also shown in Table II are the mean plasma digoxin concentrations of the operative and support dogs. To show that coronary vasoconstriction could not be caused by the low systemic digoxin concentrations observed in the operative dogs, a control cross-perfusion experiment was done in which the operative dog received 0.1 $\mathrm{mg}$ digoxin intravenously. This dose produced plasma digoxin levels comparable to or greater than those observed in the operative dogs, but coronary vascular resistance did not increase during the 30 -min period after the injection. In an additional experiment $1.0 \mathrm{mg}$ of digoxin was injected intravenously into the body of a head-perfused animal and except for a small, initial transient increase in coronary vascular resistance to $4 \%$ above control 5-min after the injection, vascular resistance at 5 -min intervals remained between -1 and $-5.6 \%$ of control throughout $1 \mathrm{~h}$ after injection. In the support animal coronary vascular resistance was consistently at or below the control levels throughout the followup period. These findings were accompanied by operative dog serum digoxin levels of $190,157,85,64$, and $48 \mathrm{ng} / \mathrm{ml}$ at $5,10,20,30$, and 50 , min after the in. jection. Support dog serum digoxin levels collected at comparable times were consistently less than 0.1 $\mathrm{ng} / \mathrm{ml}$.

\section{DISCUSSION}

These data provide direct evidence that the CNS is a major site of action of digitalis in producing neurogenic vasoconstriction in coronary vasculature. The study clearly illustrates that this CNS effect of digoxin occurs independent of direct stimulation of receptors in either the peripheral afferent or efferent autonomic nervous system. Furthermore, the data establish that the neurogenic vasoconstrictor effect of digoxin on the coronary vasculature is independent of a possible reflex response to the associated hemodynamic effects of digitalis.

The close temporal correlation of the increase in CSF levels of digoxin with its neurogenic coronary vasocontrictor effect after intravenous injection suggests a causeand-effect relationship. When the presence of digoxin is limited to the CNS by the techniques outlined, neurogenic coronary vasoconstriction is still present. This is demonstrated both in the experiments that involve injection of submicrogram amounts of digoxin into the CSF (lateral ventricles) and in the cross-perfusion experiments, in which the delivery of digitalis to the brain was blood-borne but limited to the circulation to the head. Furthermore, in cross-perfused preparations significant coronary vasoconstriction occurred early after the injection of digoxin.

Previous studies with digitalis have shown effects on the afferent and efferent autonomic nervous system. With regard to the peripheral efferent nerves, it has been demonstrated that digitalis glycosides sensitize the autonomic ganglia to chemical and neural stimulation $(13,14)$. However, during the cross-perfusion ex- 
Mean Plasma Digoxin Levels in Cross-Head Perfusion Experiments

\begin{tabular}{|c|c|c|c|c|c|c|c|c|c|c|}
\hline \multicolumn{3}{|c|}{ Dog 4} & \multicolumn{3}{|c|}{$\operatorname{Dog} 5$} & \multicolumn{3}{|c|}{$\operatorname{Dog} 6$} & \multirow[b]{2}{*}{$\begin{array}{l}\text { Donor dog } \\
\text { Mean plasma } \\
\text { digoxin }\end{array}$} & \multirow[b]{2}{*}{$\begin{array}{c}\text { Operative dog } \\
\text { mean plasma } \\
\text { digoxin }\end{array}$} \\
\hline $\begin{array}{l}\Delta \text { coronary } \\
\text { vascular } \\
\text { resistance }\end{array}$ & $\begin{array}{l}\text { Coronary } \\
\text { flow }\end{array}$ & $\begin{array}{l}\text { Mean } \\
\text { arterial } \\
\text { pressure }\end{array}$ & $\begin{array}{l}\Delta \text { coronary } \\
\text { vascular } \\
\text { resistance }\end{array}$ & $\begin{array}{l}\text { Coronary } \\
\text { flow }\end{array}$ & $\begin{array}{l}\text { Mean } \\
\text { arterial } \\
\text { pressure }\end{array}$ & $\begin{array}{l}\Delta \text { coronary } \\
\text { vascular } \\
\text { resistance }\end{array}$ & $\begin{array}{l}\text { Coronary } \\
\text { flow }\end{array}$ & $\begin{array}{c}\text { Mean } \\
\text { arterial } \\
\text { pressure }\end{array}$ & & \\
\hline$\%$ control & $\mathrm{cm}^{\mathrm{3}} / \min$ & $m m H g$ & $\%$ control & $\mathrm{cm}^{2} / \min$ & $m m \mathrm{Hg}$ & $\%$ control & $\mathrm{cm}^{3} / \mathrm{min}$ & $m m H g$ & $n g / m l$ & $n g / m l$ \\
\hline 0 & 88 & 98 & 0 & 119 & 63 & 0 & 89 & 112 & 0 & 0 \\
\hline+3.5 & 84 & 98 & +5.0 & 113 & 68 & +3.1 & 84 & 112 & $102 \pm 21$ & $5.4 \pm 2.2$ \\
\hline+4.0 & 82 & 98 & +10.2 & 109 & 68 & +3.9 & 86 & 115 & $56 \pm 5$ & $4.2 \pm 1.8$ \\
\hline+8.0 & 81 & 100 & +19.1 & 103 & 70 & +11.6 & 82 & 118 & - & - \\
\hline+10.9 & 79 & 100 & +18.4 & 106 & 72 & +15.5 & 79 & 118 & $29 \pm 5$ & $2.6 \pm 0.9$ \\
\hline+1.5 & 82 & 95 & $\begin{array}{r}+14.5 \\
\end{array}$ & 107 & 70 & +19.4 & 76 & 118 & - & - \\
\hline+8.8 & 79 & 98 & +22.4 & 103 & 72 & +27.1 & 76 & 125 & $19 \pm 3$ & $2.0 \pm 0.6$ \\
\hline+8.1 & 82 & 98 & $\begin{array}{r}+17.8 \\
\end{array}$ & 104 & 70 & +27.1 & 76 & 125 & - & - \\
\hline+8.8 & 82 & 102 & $\begin{array}{r}+17.8 \\
\end{array}$ & 104 & 70 & +34.9 & 72 & 125 & - & - \\
\hline-10.2 & 94 & 100 & +4.7 & 117 & 70 & +24.0 & 78 & 125 & - & - \\
\hline-4.5 & 92 & 98 & -7.3 & 123 & 65 & - & - & - & $11 \pm 2$ & $1.7 \pm 0.6$ \\
\hline-4.5 & 92 & 98 & -18.2 & 135 & 63 & - & - & - & - & - \\
\hline+2.7 & 87 & 100 & -11.2 & 128 & 65 & - & - & - & - & - \\
\hline
\end{tabular}

periments in the present study as well as the experiments involving the direct injection of digoxin into the CSF, sympathetic or parasympathetic ganglia were not exposed to the drug and thus cannot be implicated as the site of action for the vasoconstrictor effect observed. Thus, in the present studies, it seems unlikely that the ability of cardiac glycosides to enhance the excitability of ganglia is responsible for the coronary vasoconstrictor effect of this drug.

With regard to the afferent autonomic nervous system, the role of carotid sinus reflex effects on coronary vascular resistance has been emphasized (15-17). Gillis (6) demonstrated that the intra-arterial administration of small amounts of ouabain to the carotid bifurcations in the cat resulted in an increase in afferent nerve traffic in the carotid sinus nerve. This clearly establishes an effect of digitalis on afferent receptors in the periphery, even though the net effect of carotid sinus nerve stimulation would be to lower systemic vascular resistance by a withdrawal of efferent sympathetic activity. Recent studies in our laboratory by Stark, Sanders, and Powell (8) have demonstrated, however, not only that digitalis caused a neurally mediated vasoconstriction in the skeletal muscle bed, but also that this effect was not significantly modified by the the section of the carotid sinus nerve. The studies of Hamlin, Willerson, Garan, and Powell (9) demonstrated that digitalisinduced coronary vasoconstriction was mediated through alpha adrenergic nerve fibers and provided evidence against a major role of afferent receptors in heart or lung by showing similar coronary vasoconstriction after bilateral vagotomy. Under the experimental conditions employed, the present study provides data against the possibility of other afferent receptor sites contributing substantially to this effect of digitalis and localizes a major site of action to the CNS.

The presence of alpha adrenergic receptors in the coronary vascular bed has been demonstrated previously (18-23), but a clinically important role has not generally been ascribed to them. Hamlin et al. (9) demonstrated that coronary vasoconstriction caused by intravenous digoxin could be abolished completely by previous alpha adrenergic receptor blockade with phenoxybenzamine or by ganglionic blockade with mecamylamine. This latter study also demonstrated that an associated decrease in myocardial oxygen consumption could not account for the observed vasoconstrictor effect of digoxin, thus clearly establishing that the mechanism of the neurogenic vasoconstrictor effect of digitalis is through alpha adrenergic receptor stimulation.

The present data do not allow a precise localization of the site of action of digoxin within the CNS in producing neurogenic vasoconstriction. Injection of digoxin into the lateral ventricles produced a rise in coronary vascular resistance that was more gradual than that achieved with the intravenous injection of the drug and did not reach substantial elevations until a later time after the injection. It is of interest in this regard that Gillis (6) has demonstrated that the increase in efferent sympathetic nerve firing associated with intravenous ouabain administration in the cat is still present after midbrain section, suggesting that the site of action of ouabain in their experiments was at the level of the brain stem.

The present study also provides data on the kinetics of digoxin transit across the blood-brain barrier. $\mathrm{Di}$ goxin, a relatively nonpolar compound, enters the CSF rapidly and is detected within the first 2 min after in-

Coronary Vasoconstrictor Effect of Digoxin 
travenous injection. Digoxin levels in the CSF continue to rise until $15 \mathrm{~min}$ after injection and then slowly decline. Maximum concentrations free in the CSF in the present experiments were of the order of $3 \times 10^{-0} \mathrm{M}$, and effective concentrations at CNS tissue receptors may have been substantially higher. This demonstration of the ability of digoxin to cross the blood-brain barrier suggests the relevance of continuing investigation of its effects on the CNS.

The CNS-mediated neurogenic vasoconstrictor effect of digoxin described in this study may have important clinical implications. For example, the vasoconstriction occurring soon after the intravenous administration of this cardiac glycoside is seen at a time that corresponds to the clinical observation of ventricular tachyarrhythmias (24) and the sporadically reported occurrence of angina pectoris (25) and pulmonary edema $(24,26)$. These deleterious side effects of digoxin could be related at least in part to the neurogenic vasoconstrictor effect of the drug on the coronary and/or peripheral circulation. An evaluation of the neurogenic vascular resistance effects of cardiac glycosides against a background of varying levels of sympathetic activity and congestive heart failure remains to be carried out, both in the physiology laboratory and at the bedside.

\section{ACKNOWLEDGMENTS}

The authors wish to thank Mr. J. L. Guerrero, Mr. Brian Effron, and Mr. Michael A. Bissanti for their technical assistance, Miss Donna M. Lingis for her secretarial assistance, and Miss Marcia Jackson for performing the digoxin radioimmunoassays.

This work was supported in part by NIH Grants-in-Aid HL 13435, HL 14292, HL 14325, and NIH Grant HEPP 06664 .

\section{REFERENCES}

1. Ross, J., Jr., J. A. Waldhausen, and E. Braunwald. 1960. Studies on digitalis. I. Direct effects on peripheral vascular resistance. J. Clin. Invest. 39: 930-936.

2. Mason, D. T., and E. Braunwald. 1964. Studies on digitalis. X. Effects of ouabain on forearm vascular resistance and venous tone in normal subjects and in patients in heart failure. J. Clin. Invest. 43: 532-543.

3. Harrison, L. A., J. Blaschke, R. S. Phillips, W. E. Price, M. deV. Cotten, and E. D. Jacobson. 1969. Effects of ouabain on the splanchnic circulation. $J$. Pharmacol. Exp. Ther. 169: 321-327.

4. Vatner, S. F., C. B. Higgins, D. Franklin, and E. Braunwald. 1971. Effects of a digitalis glycoside on coronary and systemic dynamics in conscious dogs. Circ. Res. 28: 470-479.

5. Quest, J. A., and R. A. Gillis. 1971. Carotid sinus reflex changes produced by digitalis. J. Pharmacol. Exp. Ther. $177: 650-661$.

6. Gillis, R. A. 1969. Cardiac sympathetic nerve activity: changes induced by ouabain and propranolol. Science. (Wash. D. C.). 166: 508-510.
7. McLain, P. L. 1969. Effects of cardiac glycosides on spontaneous efferent activity in vagus and sympathetic nerves of cats. Int. J. Neuropharmacol. 8: 379-387.

8. Stark, J. J., C. A. Sanders, and W. J. Powell, Jr. 1972. Neurally mediated and direct effects of acetylstrophanthidin on canine skeletal muscle vascular resistance. Circ. Res. 30: 274-282.

9. Hamlin, N. P., J. T. Willerson, H. Garan, and W. J. Powell, Jr. 1974. The neurogenic vasoconstrictor effect of digitalis on coronary vascular resistance. J. Clin. Invest. 53: 288-296.

10. Gregg, D. E., and L. C. Fisher. 1963. Blood supply to the heart. Handb. Physiol. Sec. 2, 2: 1517-1584.

11. Smith, T. W., V. P. Butler, Jr., and E. Haber. 1969. Determination of therapeutic and toxic serum digoxin concentrations by radioimmunoassay. N. Engl. J. Med. 281: 1212-1216.

12. Smith, T. W., and E. Haber. 1970. Digoxin intoxication: the relationship of clinical presentation to serum digoxin concentration. J. Clin. Invest. 49: 2377-2386.

13. Perry, W. L. M., and H. Reinert. 1954. The action of cardiac glycosides on autonomic ganglia. $\mathrm{Br}$. J. Pharmacol. 9: 324-328.

14. Knozett, H., and E. Rothlin. 1952. Effect of cardioactive glycosides on a sympathetic ganglion. Arch. Int. Pharmacodyn. Ther. 89: 343-352.

15. Feigl, E. O. 1968. Carotid sinus reflex control of coronary blood flow. Circ. Res. 23: 223-237.

16. Vatner, S. F., D. Franklin, R. L. Van Citters, and E. Braunwald. 1970. Effects of carotid sinus nerve stimulation on the coronary circulation of the conscious dog. Circ. Res. 27 : 11-21.

17. Hackett, J. G. F. M. Abboud, A. L. Mark, P. G. Schmid, and D. D. Heistad. 1972. Coronary vascular responses to stimulation of chemoreceptors and baroreceptors. Evidence for reflex activation of vagal cholinergic innervation. Circ. Res. 31: 8-17.

18. Berne, R. M., H. DeGeest, and M. N. Levy. 1965. Influence of the cardiac nerves on coronary resistance. Am. J. Physiol. 208: 763-769.

19. Granata, L., R. A. Olsson, A. Huvos, and D. E. Gregg. 1965. Coronary inflow and oxygen usage following cardiac sympathetic nerve stimulation in unanesthetized dogs. Circ. Res. 16: 114-120.

20. Feigl, E. O. 1967. Sympathetic control of coronary circulation. Circ. Res. 20: 262-271.

21. Pitt, B., E. C. Elliot, and D. E. Gregg. 1967. Adrenergic receptor activity in the coronary arteries of the unanesthetized dog. Circ. Res. 21: 75-84.

22. Zuberbuhler, R. C., and D. F. Bohr. 1965. Responses of coronary smooth muscle to catecholamines. Circ. Res. 16: $431-440$.

23. Ross, G., and D. G. Mulder. 1969. Effects of right and left cardiosympathetic nerve stimulation on blood flow in the major coronary arteries of the anaesthetized dog. Cardiovasc. Res. 3: 22-29.

24. Cohn, J. N., F. E. Tristani, and I. M. Khatri. 1969. Cardiac and peripheral vascular effects of digitalis in clinical cardiogenic shock. Am. Heart J. 78: 318-330.

25. Balcon, R., J. Hoy, and E. Sowton. 1968. Haemodynamic effects of rapid digitalization following acute myocardial infarction. Br. Heart J. 30: 373-376.

26. Bayliss, R. I. S., M. J. Etheridge, A. L. Hyman, H. G. Kelly, J. McMichael, and E. A. S. Reid. 1950. The effect of digoxin on the right ventricular pressure in hypertensive and ischaemic heart failure. Br. Heart $J$. 12: 317-326. 